Marquette University

e-Publications@Marquette

8-1-2017

\title{
Change and Continuity in the Role of State Attorneys General in the Obama and Trump Administrations
}

Paul Nolette

Marquette University, paul.nolette@marquette.edu

Colin Rovost

University of London

Accepted version. The Journal of Federalism, Vol. 48, No. 3 (July 1, 2018): 469-494. DOI. (C) 2018

Oxford University Press. Used with permission. 
Marquette University

\section{e-Publications@Marquette}

\section{Political Science Faculty Research and Publications/College of Arts and Sciences}

This paper is NOT THE PUBLISHED VERSION; but the author's final, peer-reviewed manuscript. The published version may be accessed by following the link in the citation below.

Publius: the Journal of Federalism, Vol. 48, No. 3 (May 18, 2018): 469-494. DOI. This article is (C) Oxford University Press and permission has been granted for this version to appear in $\underline{\text { e- }}$ Publications@Marquette. Oxford University Press does not grant permission for this article to be further copied/distributed or hosted elsewhere without the express permission from Oxford University Press.

\section{Contents}

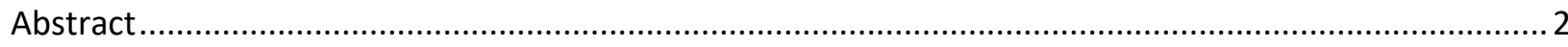

Increasing Intergovernmental Conflict during the Trump Presidency..................................................... 4

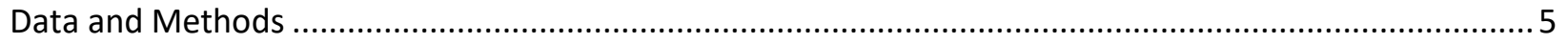

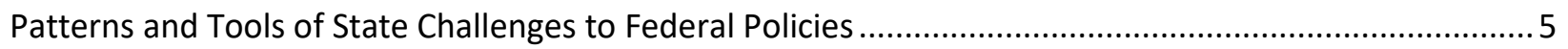

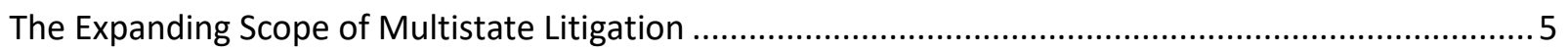

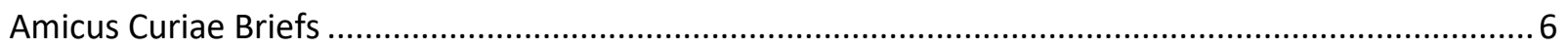

Sign-on Letters and Administrative Comments ........................................................................

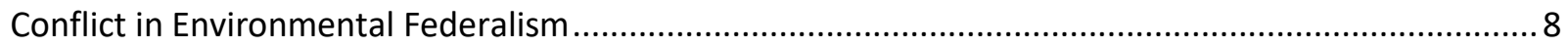

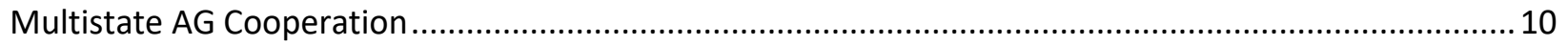

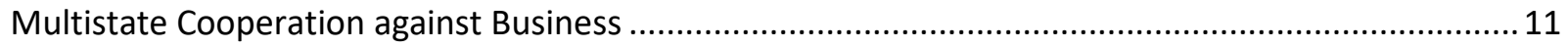

Multistate Cooperation: Drug Companies and Opioids................................................................... 13

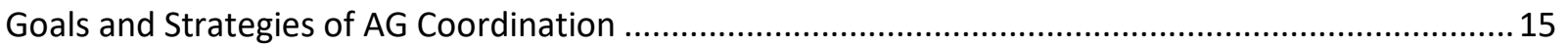

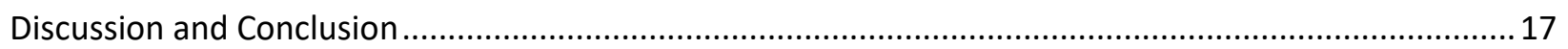

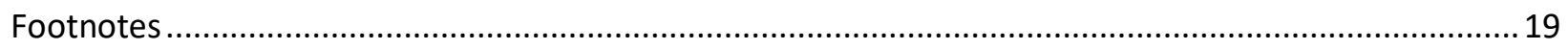

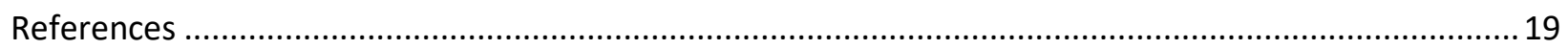




\title{
Change and Continuity in the Role of State Attorneys General in the Obama and Trump Administrations
}

\author{
Paul Nolette \\ Marquette University, Milwaukee, WI \\ Colin Provost \\ University College London, London, England
}

\begin{abstract}
During the Trump Administration, state attorneys general (AGs) have become entrenched as integral policymaking actors in the United States. Their expanding policymaking role fits broader patterns of polarized politics, as partisan coalitions of AGs are increasingly willing to sue the federal government, a trend that gathered steam in the Obama Administration and has reached a crescendo in Trump's first year. However, state AGs do cooperate, particularly in corporate litigation to address allegedly widespread, illegal behavior. Utilizing a comprehensive dataset of multi-state lawsuits and Supreme Court amicus briefs, we identify continuity and change in how AGs have employed their powers, by examining their activities during the first year of the Trump presidency and placing these activities in the context of previous administrations. This analysis is accompanied by a pair of case studies, one on conflictual AG environmental litigation and another on bipartisan efforts to address the opioid epidemic. Both demonstrate AG's prominent policymaking power, a power unlikely to abate anytime soon.
\end{abstract}

In the first year of Donald Trump's presidency, partisan divisions that reached record levels during Barack Obama's Administration grew even larger. The percentage of Americans identifying as either consistently liberal or consistently conservative is now far higher than it was even a decade previously (Pew Research Center 2017). This deepening polarization has been felt across the intergovernmental landscape, as political actors at various levels of government have employed a wider array of policy tools in a battle to gain political advantage. Conservative state legislators have, for example, used preemption law to block local governments from pursuing progressive policy goals (Riverstone-Newell 2017). State policymakers across the political spectrum have considered proposals to 'nullify' national policies (Olson, Callaghan, and Karch 2018), and partisan considerations have become more important to governors operating in national politics (Jensen 2017).

This partisan behavior has also been apparent among state attorneys general (AGs), who have been some of the most active state-level actors in the early part of the Trump Administration. Even before 
Trump was sworn into office, Democratic AGs pledged to take strong action through multi-state lawsuits to push back on his policy priorities. Washington State AG Bob Ferguson, for example, stated that he would be "on the first line of defense against a Trump Administration" that acted unconstitutionally (Hurley 2016). Meanwhile, New York AG Eric Schneiderman immediately prepared to monitor the administration's executive agencies closely (Debenedetti 2017). After Trump's inauguration, AGs made good on their promises of aggressive action, first suing over Trump's order banning persons from certain countries from entering the United States and soon after litigating across a range of issues including immigration, the environment, education, and health care. These actions have led to lower federal court decisions halting implementation of the travel bans, blocking the administration from rescinding Obama's Deferred Action for Childhood Arrivals (DACA) order, and preventing Trump officials from withholding funds from jurisdictions declining to help carry out certain federal immigration policies. AG lawsuits have also complicated other Trump administration policies by leading to lower court judgments blocking Trump officials' efforts to roll back Obama administration environmental regulations and reinterpret rules regarding the contraceptive coverage that employers are required to provide pursuant to the Affordable Care Act.

Scholars have documented the increasingly prominent role of AGs in national policy-making and governance in recent years, noting that AGs' activism has both intensified and become more partisan over time (Nolette 2015a, 2017). This was particularly true in Obama's second term, when the scope of AG conflict expanded rapidly, most notably through multi-state lawsuits brought by Republican AGs against Obama Administration actions (Nolette 2017). At the same time, AGs have continued to cooperate on a bipartisan basis, particularly in investigating alleged corporate fraud (Provost 2010, 2014). This article builds upon this previous work by examining how AGs' burgeoning national role in the early part of Trump's presidency reflects continuity and change from earlier years.

We advance four main arguments. First, AGs' conflicts with the federal government intensified sharply during Trump's first year. Even in comparison with the George W. Bush and Obama presidencies-both of which featured considerable intergovernmental conflict originating with the AGs - the scope of AG activism has been more frequent, addressed a broader range of issues, and emerged far earlier in the president's term in office. As part of this activism, state AGs are not only aggressively utilizing traditional policy tools, such as multi-state lawsuits and amicus briefs, but are also expanding their use of other tools such as authoring joint letters to federal officials. Second, this federal-state conflict has been overwhelmingly partisan, continuing trends emerging in the second half of Obama's presidency. Third, despite this intensifying partisan conflict in activism targeting the federal government, AGs have carved out a few areas of bipartisan cross-state cooperation. This has been particularly true in multistate investigations of corporate fraud and across some areas of criminal justice. Fourth, we consider how the expanded arsenal of resources at AGs' disposal has affected their work. Specifically, we analyze the expanding policy networks in which they operate, their ability to respond to federal policy initiatives rapidly, as well as their use of soft-law tactics such as jointly authored letters to members of Congress.

This article fits into the broader literature on patterns of conflict and cooperation in American federalism. Since the 1970s, the U.S. political system has seen a shift away from cooperative federalstate policy implementation to a more "coercive" federalism whereby the federal government has sought to expand its power at the expense of the states (Bowman and Krause 2003; Conlan 1991; Kincaid 1990). In a number of different policy areas, state officials, including AGs, responded by joining forces and creating policy initiatives that served as de facto national public policy (Bowman 2004; Lynch 
2001; Nolette 2015a; Provost 2003; Zimmerman 1998). Coercive federalism has shown little retreat, while levels of polarization have markedly increased, both among states and between the federal and state governments (Conlan 2017; Conlan and Posner 2016; Nolette 2017). We examine how these trends have affected the activities of state AGs in state and federal policymaking.

This article proceeds in three main parts. First, we examine federal-state conflict during the first year of the Trump Administration, placing this conflict within the historical trends of nationalized AG activism. Utilizing a dataset on AG multi-state lawsuits from 1980 through 2017, we examine the level of intergovernmental conflict over time. We then examine in a case study how this conflict is manifested in the contentious case of environmental regulation. Here we look more closely at the partisan characteristics of state-federal disputes. Second, we utilize the same lawsuit dataset to examine AG litigation against corporations, which has featured greater cross-state cooperation. We include a case study of the multistate investigation into the opioid crisis, which has emerged as the most comprehensive bipartisan AG effort during the early Trump Administration. We conclude by highlighting several emerging issues involving $A G$ activism and suggesting areas of future research on this important source of cross-state conflict and cooperation.

\section{Increasing Intergovernmental Conflict during the Trump Presidency}

Only days after Trump's inauguration, AGs began pushing back on the president's priorities. Several Democratic AGs banded together to challenge Trump's immigration executive orders and have since challenged federal policy in areas including the environment, education, civil rights, and regulation of internet providers (a policy referred to as "net neutrality"). Meanwhile, Republican AGs have formed their own coalitions to support Trump's policies against the efforts of their Democratic colleagues.

This AG-driven conflict, which we examine below, has roots in broader patterns of conflict that have emerged in recent decades of American federalism. The cooperative federalism of the 1960s gave way to the coercive federalism of the 1970s and beyond, an era often characterized by unfunded mandates, preemption laws and other top-down regulatory requirements (e.g., Conlan 1991; Kincaid 1990). As policymaking became more nationalized, polarization across all levels of government increased. The ideological preferences of state level policymakers increasingly mirrored those at the federal level, broadening the scope of partisan conflict across the landscape of American federalism (Bulman-Pozen 2014; Conlan 2017; Conlan and Posner 2016).

In this setting, AGs developed multistate mechanisms in order to have more influence in national policymaking. Dismayed with the Reagan Administration's hands-off approach to social and economic regulation, AGs began in the 1980s to band together in multi-state lawsuits against industries and in a way that effectively allowed AGs to stand in for allegedly absent federal regulators (Clayton 1994; Lynch 2001; Nolette 2015a; Provost 2003; Zimmerman 1998). These Reagan-era strategies proved enduring, with AGs cooperating on high-dollar settlements that simultaneously brought money to state coffers and served as a regulatory mechanism across industries such as tobacco and pharmaceuticals (Derthick 2002, Nolette 2015a). Meanwhile, AGs used multistate actions to directly challenge federal policy, seeking to push back on what increasingly polarized groups of AGs viewed as either the federal government's failure to adequately address regulatory issues or Washington's meddling in state policymaking.

State AGs' engagement in national policy disputes increased alongside growing resources that supported this activity. First, the networks within which AGs operate have expanded, as business 
organizations and non-governmental organizations contribute money to the respective Republican and Democratic Attorneys General Associations (RAGA and DAGA), and to individual AG campaigns, as well as provide assistance with AG litigation (Lipton 2014). Second, AGs have learned to anticipate new federal rules and draw on these networks to craft legal responses to federal policies almost as soon as they are announced. Finally, in addition to the formal legal tools of direct litigation, multi-state investigations, and amicus briefs, state AGs have also learned to rely on what might be termed "soft power" tools, such as jointly authored letters and comments addressed particularly to members of Congress and to federal agencies.

\section{Data and Methods}

Our data analysis involves two steps. As our primary goal is to analyze how patterns of conflict and cooperation have continued into the Trump Administration, we look first at the scope and participation patterns in multi-state litigation brought against the federal government as well as against the private sector. We also examine these same patterns with respect to amicus briefs filed in Supreme Court cases. ${ }^{1}$ In each instance, we rely on data from the Clinton, George W. Bush, Obama, and Trump administrations to observe patterns over time.

Following this analysis of descriptive, quantitative data, we turn to case studies on environmental regulation and on the opioid crisis to analyze more deeply how conflict and cooperation emerge in multi-state litigation. Specifically, we analyze environmental policy as a case of intensifying conflict, both in the latter half of the Obama administration and at the start of Trump's presidency. In contrast, the AGs' opioid investigation is a case of bipartisan cooperation to address an issue with wide-ranging and significantly harmful effects across the country. In each case, we note the importance of expanded AG resources, as AGs have benefitted from expanding policy networks and a broader array of legal tools with which to fight their battles.

\section{Patterns and Tools of State Challenges to Federal Policies}

\section{The Expanding Scope of Multistate Litigation}

To examine federal-state conflict over time, figure 1 indicates the number of lawsuits AGs have brought against the federal government from 1980 through 2017. Numbers of legal actions against the federal government represent our measure of conflict with the federal government, while different policy areas represent the breadth with which these conflicts apply.

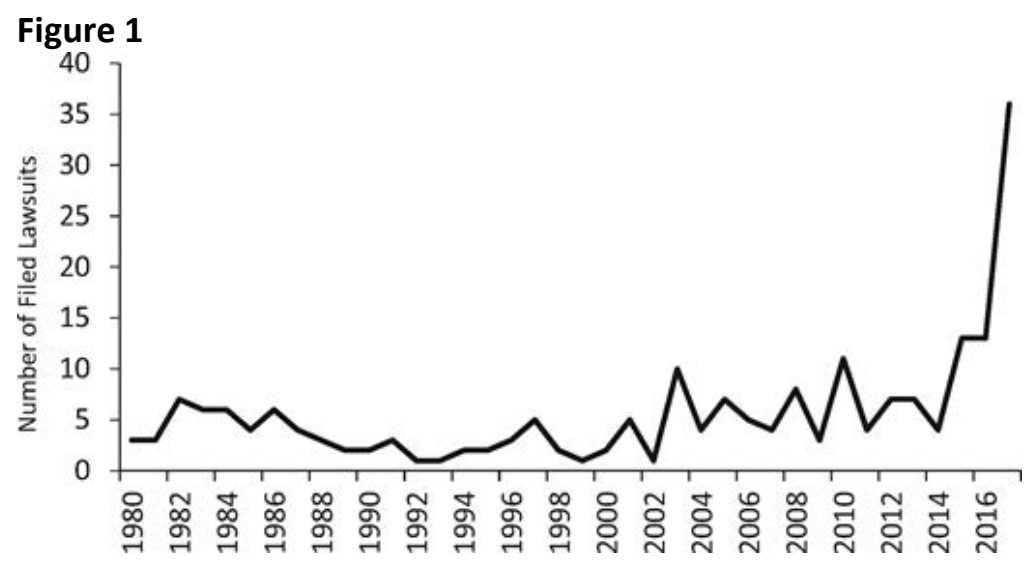

Number of multi-state legal actions brought against the federal government, 1980-2017. 
These data suggest both an intensification and expansion of AG conflict over time. During the Clinton Administration, AGs brought eighteen multistate actions against the federal government, all of which involved environmental issues. The number of AG lawsuits increased to forty-four under the Bush Administration, with environmental policy again being the dominant area of focus. In short, state officials during this time were becoming bolder in challenging the federal government, but the scope of this multistate conflict was limited mainly to environmental policy.

This pattern began changing under the Obama Administration. In addition to continued growth of multistate challenges to federal policy, these challenges were increasingly broad in policy scope, particularly during Obama's second term. While environmental issues remained a prominent area of contestation of the sixty multistate lawsuits brought against the Obama Administration, a significant proportion of litigation involved other policy areas. The cases not dealing with environmental issues represented challenges to some of the Obama Administration's signature policy achievements, including the Dodd-Frank Act, Deferred Action for Parents of Americans and Lawful Permanent Residents (DAPA), rules on transgender bathroom access, and, most notably, the Affordable Care Act. These lawsuits in salient areas of health care, immigration, financial reform and civil rights indicated a new willingness on the part of conservative AGs to challenge a breadth of federal policies, particularly in Obama's second term. These actions also reflected a harmonious congruence in policy goals with congressional Republicans. If House and Senate Republicans could not stop the president's policies through legislative channels, Republican AGs might (and in several cases did) stop them in court.

The pattern of partisan challenges to the federal government has dramatically intensified in Donald Trump's first year in office. Coalitions of Democratic AGs brought thirty-six lawsuits against the Trump Administration in 2017 alone, more than the total number of multistate actions brought during the entirety of the Clinton Administration and well over half the number of lawsuits filed during either the George W. Bush or Obama presidencies. Sixteen of these thirty-six legal actions involved environmental protection. This is illustrative of two important trends. First, environmental protection has remained highly salient during the Trump Administration. Second, other legal actions have continued to be brought in highly salient policy areas, such as immigration, health care and education-policy areas that have also ranked high on President Trump's agenda. These lawsuits have thus followed a trend of rapidly increasing partisan conflict between states and the federal government.

\section{Amicus Curiae Briefs}

In addition to directly litigating against the federal government, AGs have sought to influence national policy through other forms of multistate activism. One method is through filing amicus briefs in federal court, an activity that has become significantly more polarized over time.

As an indication of the rising polarization in amicus brief filings, we analyze trends in amicus filings at the U.S. Supreme Court, both at the certiorari and merit stages, since the Clinton Administration. Table 1 indicates the number of partisan briefs filed, which we define as briefs on which 80 percent or more of the states on a given brief are from the same party, ${ }^{2}$ thereby measuring the levels of partisanship within the brief-writing coalitions. We also examine the number of cases in which states filed briefs in support of both the respondents and the petitioners, given that the presence of different groups of states on opposite sides of one case also represents a measure of conflict amongst AGs. 
Table 1. Average number of amicus briefs filed across presidential administrations

$\begin{array}{lllll} & \text { Clinton } & \text { Bush } & \text { Obama } & \text { Trump (2017) } \\ \text { Cert Amicus Briefs } & 10.25 & 10.88 & 12.88 & 20 \\ \text { Merit Amicus Briefs } & 26.88 & 30.63 & 29.38 & 28 \\ \text { Total Amicus Briefs } & 37.13 & 41.50 & 42.25 & 55 \\ \text { Partisan Briefs } & 7.13(19.20 \%) & 10.50(25.30 \%) & 18.75(44.4 \%) & 43(78.18 \%) \\ \text { State Opposition Briefs } & 2.25(6.10 \%) & 3.88(9.30 \%) & 5.13(12.14 \%) & 11(20.00 \%)\end{array}$

Table 1 presents the average number of each type of brief across the four presidential administrations. As the first three rows indicate, the number of merit briefs (filed after the Court has agreed to hear a case and the focus is on influencing the outcome) has been relatively stable over time. There is however, a gradual increase in the average number of certiorari briefs (filed when the Court is deciding whether to place a case on its docket), particularly as we move from the Bush to the Obama administrations. These data reveal that AGs have become more active in the agenda-setting stage of Supreme Court decisions, crafting briefs to get some cases heard, or not heard. While there is only one year's worth of data for the Trump Administration so far, the large number of briefs for 2017 suggests that the overall pattern of AGs attempting to influence the Court at the cert stage will remain.

Next, we look at the average number of partisan briefs that have been filed over the four administrations, as well as the average proportion of partisan briefs filed per administration. Here the trend is much stronger, as the average proportion of partisan briefs rises from 19.20 percent under Clinton to 25.30 percent under Bush and then rises to 44.44 percent under Obama. Again, the amount of data available for the Trump Administration does not offer a complete picture, but it does show this pattern continuing in an unambiguous fashion, as 78.18 percent of the briefs filed early in the Trump Administration are partisan. This trend provides strong evidence for the idea that state advocacy before the Supreme Court is becoming more partisan and is characterized much more by cooperation within parties than across the parties. At the same time, there is evidence of interstate conflict in the form of states filing briefs on both sides of one case. The final row of table 1 shows a gradual increase in the number of briefs over time, with 20 percent of the cases in which AGs filed amicus briefs in 2017 featuring competing sets of AG coalitions taking opposite sides in the case.

These data include only multistate amicus filings in U.S. Supreme Court, but AGs exhibited similar partisan behavior in their amicus filings in federal lower courts as well. Indeed, all of the fifty-seven multistate amicus filings across forty-five lower federal court cases in 2017 were partisan briefs. This suggests that the AGs' lower court amicus behavior is at least as partisan as their more high-profile filings in U.S. Supreme Court, if not more so.

\section{Sign-on Letters and Administrative Comments}

AGs also engaged with issues of national scope via letters directed to federal policymakers and private entities as well as comments filed during the notice-and-comment stage of administrative rulemaking. While this activity occurred in previous administrations as well, a shift towards the more partisan use of 
these strategies was apparent early in Trump's presidency-especially in comparison to the similar period in Obama's presidency.

In President Obama's first year, AGs filed twenty-four multistate letters or comments directed to federal policymakers or private corporations. The bulk of these, 79 percent, featured a bipartisan coalition of AGs. ${ }^{3}$ Examples included a bipartisan letter urging the quick confirmation of Eric Holder as U.S. Attorney General, comments urging the Federal Trade Commission (FTC) to adopt stricter regulations of mortgage lenders, and a letter asking the federal government to investigate bonuses paid to AIG executives following the federal bailout of the company.

In contrast, both the quantity and partisanship of these actions were far greater in Trump's first year. AGs filed 109 multistate letters and comments in 2017 alone, only 19 percent of which featured bipartisan coalitions. Most of these letters and comments were sharply partisan, involving AG Republican coalitions (22 percent of the letters and comments) or their Democratic AG counterparts (59 percent). The partisan activity covered a wide range of issues. Republican AGs, for example, urged Congress to confirm various presidential nominees, eliminate Obama-era regulations, and allow stateissued concealed-carry gun permits to apply even in states refusing to issue them. Democratic AGs opposed these efforts and urged Congress and the executive branch to adopt stronger federal regulations in areas such as education, the environment, and workers' rights.

\section{Conflict in Environmental Federalism}

We now undertake a more detailed look at the conflicts between AGs and the federal government in environmental policy and regulation. Our quantitative data indicate that this policy area is one of the most consistently contentious, particularly between states and the federal government. In this case study, we analyze how conflict in environmental policy has played out across the Obama and Trump Administrations. In so doing, we explicitly examine the role of partisanship and the expanded use of AG resources such as widening policy networks of allies on both sides, the use of soft power, and the ability to respond rapidly to new federal initiatives. Because space does not permit a discussion of all major environmental conflicts during the period, we focus on a small sample of the most high-profile cases.

While there has long been conflict between states and the federal government in environmental federalism, it has become particularly noticeable and evident during the Obama and Trump Administrations (Nolette 2017). State environmental lawsuits against the federal government expanded rapidly during the Bush Administration and continued apace under Obama, and the trend under Trump signals continually increasing levels of conflict. Each of these administrations has been accused by its political opponents of overstepping its bounds in its environmental policymaking. President Obama pledged to make action on climate change a lasting part of his legacy (Broder 2008), but the loss of the Democratic majority in both the House (after 2010) and the Senate (after 2014) forced the administration to adopt a more unilateral policymaking stance. New policies were created primarily through executive orders and rulemaking, rather than through the legislative process (Davenport 2015). Republican AGs challenging Obama's environmental initiatives claimed that such unilateral actions represented a violation of the separation of powers or a misuse of the powers granted to the executive branch by existing legislation, such as the Clean Air Act (Biskupic 2012; Howell 2013). 
During the Trump Administration the script has flipped, as Democratic AGs have mobilized aggressively against federal policies. Trump's nominee to head the Environmental Protection Agency (EPA), Scott Pruitt, who as Oklahoma AG filed or joined numerous lawsuits against the Obama administration, faced criticism immediately from those concerned that he would fiercely advocate for fossil fuel interests, rather than environmental interests (Davenport and Lipton 2017). Rather than pursuing the onerous process of repealing Obama rules, Pruitt sought to delay their implementation (Davenport 2017; McQuaid 2017). As Republican AGs once claimed that Obama's actions exceeded his authority, Democratic AGs argued that Trump administration delays amounted "to an impermissible end-around well-established administrative law requirements governing the process for repeal of federal rules" (California Attorney General 2017). The Democratic AG coalition has since referenced this argument in a series of comments and legal actions directed to the EPA, prompting the agency to walk back its delay strategy on new smog rules in August 2017 (New York Attorney General 2017a).

A major component of the partisan conflict over environmental federalism has been the increased utilization of new resources, particularly the expanding web of allies each side has cultivated. Numerous government, business, and civil society organizations have taken an interest in-and have sought to influence-their activities, especially in environmental regulation. For Democratic AGs, this has meant having loose alliances with environmental groups, such as the Sierra Club, the National Resource Defense Council (NRDC) and the Environmental Defense Fund (EDF), all organizations that argue cases in court on behalf of environmental interests. For example, in the U.S. Court of Appeals for the D.C. Circuit in July 2017, the NRDC successfully turned back an attempt by the EPA to delay implementation of a rule requiring oil and gas companies to fix methane leaks in their equipment (Flitter 2017). Upon Trump's inauguration, he ordered the freezing of several new rules, including one designed to limit mercury discharge from dental offices (Stempel 2017); after the NRDC sued, the rule was restored in June 2017 (Volcovici 2018). Groups such as the NRDC and the Sierra Club informally share resources and information, as well as a revolving door between government and civil society, as a number of NRDC staff formerly worked in AG offices.

On the Republican side, AGs responsible for litigating environmental rules have developed ever closer relationships with energy interests. As Oklahoma AG, Pruitt forged relationships with a number of energy companies, bringing them under the conservative RAGA tent and helping raise massive new sums of money for the organization itself (Lipton 2014). The enthusiasm of energy companies to donate money to Republican AG campaigns and to RAGA should not be surprising, given that their assistance and advice was warmly accepted from AGs such as Pruitt. In each instance, energy industry lobbyists drafted letters suggesting regulatory changes that AGs could send, nearly unchanged, to federal officials (Lipton 2014). As a result of such relationships, RAGA has been able to raise vast amounts of money, with DAGA trying to catch up, leading to a financial "arms race" between the two organizations (Neuhauser 2017).

The result has been that Republican AGs are often in lockstep with energy and manufacturing companies-a trend noticeable in the coalition's legal battle against the Obama Administration's Clean Power Plan (CPP). Crafted by the EPA in 2015, the CPP was an ambitious proposal which mandated that by 2030, American power plants had to reduce emissions by 32 percent from 2005 levels. In anticipation of the regulation, the U.S. Chamber of Commerce coordinated with Republican officials in early 2014 on 
legal strategy to fight the new rules (Davenport and Davis 2015). Building on this foundation, executives from Murray Energy and other energy companies met with Republican AGs at RAGA's summer retreat in August 2015 (Davenport and Lipton 2017) to discuss litigation strategies to combat Obama's proposed rules. This level of preparation enabled the Republican AGs to file suit against the CPP almost as soon as the rules were officially published in the Federal Register in late 2015-a significant example of AGs' ability to rapidly respond to new federal initiatives and delay them before implementation can begin. The AGs had the support of large numbers of energy and manufacturing companies, business groups and Senate Majority leader Mitch McConnell, who urged individual states not to submit state implementation plans under the new rules (Davenport and Davis 2015).

At the start of the Trump Administration, Democratic AGs were well-positioned to continue using the same tactics Republican AGs had employed under Obama. After Trump in March 2017 signed an executive order "to start the complex and lengthy legal process of withdrawing and rewriting the...Clean Power Plan..." (Davenport and Rubin 2017), a week later, New York AG Schneiderman, leading a coalition of seventeen states, filed a challenge to the order (Valdmanis 2017). When EPA Administrator Pruitt formally announced in October 2017 that the EPA would begin the work of repealing the CPP, Schneiderman announced, on the same day, his intention to sue to stop the rule's repeal along with sixteen other Democratic AGs (Davenport and Rubin 2017). The speed with which Schneiderman responded to the EPA's plans to scrap the CPP is again a prime example of the rapid response that AGs engage in, as they anticipate federal policies and have legal counter-attacks crafted as soon as those federal policies are announced. At the same time, Republican AGs wrote to Pruitt in March 2018, advising him to scrap the CPP without a replacement and give the states more leeway to devise their own emission-reduction plans (Heikkinen 2018).

Finally, Democrats have also cultivated the use of soft power or tactics when combatting the Trump Administration. As Democratic AGs expected weakened environmental rules and policies favoring fossil fuels under Trump, they wrote multiple letters early in the Trump Administration. In March 2017, twelve AGs wrote to the House and Senate Appropriations committees, urging both not to cut any funding for the EPA (Office of Rhode Island Attorney General 2017). In the following month, fourteen Democratic AGs wrote a letter to President Trump, urging him not to renege on the U.S. commitment to the Paris Climate Agreement (New York Attorney General 2017b). One month later, ten Republican AGs signed a letter to the president, urging him to pull out of the agreement (Siciliano 2017), thus reflecting the level of interstate conflict on the issue. This use of soft power is another tool in the arsenal of AGs, reflecting their expanded power and policy networks.

\section{Multistate AG Cooperation}

Despite the rising tide of AG conflict apparent across various policy areas and strategies, some crossstate bipartisan cooperation has remained. As Nolette (2014) noted in his study of multistate amicus briefs during the Obama era, criminal procedure issues tended to attract greater bipartisan involvement in comparison to other policy areas. The same has held true in President Trump's first year. Half of the bipartisan amicus briefs filed in 2017 (six of twelve) were related to criminal procedure, including the high-profile cases of United States v. Microsoft and Carpenter v. United States. Likewise, the small subset of multistate letters and comments featuring bipartisan cooperation included several criminal process 
and adjacent issues, including letters urging Congress to fund prosecutions of elder abuse and assist law enforcement in combatting online sex trafficking.

\section{Multistate Cooperation against Business}

The most prominent cooperative AG efforts during the Trump presidency remain the largely bipartisan efforts to address corporate practices that allegedly harm state interests. This continues a trend through several earlier administrations, which included bipartisan investigations in the 1980s and 1990s demanding more accurate consumer labelling by food producers (Calvani 1989), the forty-six-state tobacco settlement that restructured the regulatory environment for the entire tobacco industry (Derthick 2002), and litigation against pharmaceutical companies aiming to alter their marketing and pricing practices (Nolette 2015b). Similar activities have been prominent during the Obama and Trump presidencies, including the forty-nine-state mortgage-related settlement with the five largest banks in 2012 and a \$120 million settlement in 2017 between all fifty states and General Motors over the company's defective ignition switches.

These settlements tend to cluster around four general areas of litigation: consumer protection, antitrust, health care fraud, and environmental enforcement. Figure 2 illustrates trends in multi-state litigation against businesses between 1980 and 2017. These cases initially spiked during the Clinton Administration, when a total of 140 multi-state lawsuits were settled, with a gradual increase in actions over the eight-year period. Ninety-seven of these lawsuits (69 percent) were consumer protection lawsuits, while most of the rest are antitrust lawsuits. Very few private health care or environmental lawsuits were filed during the Clinton Administration.

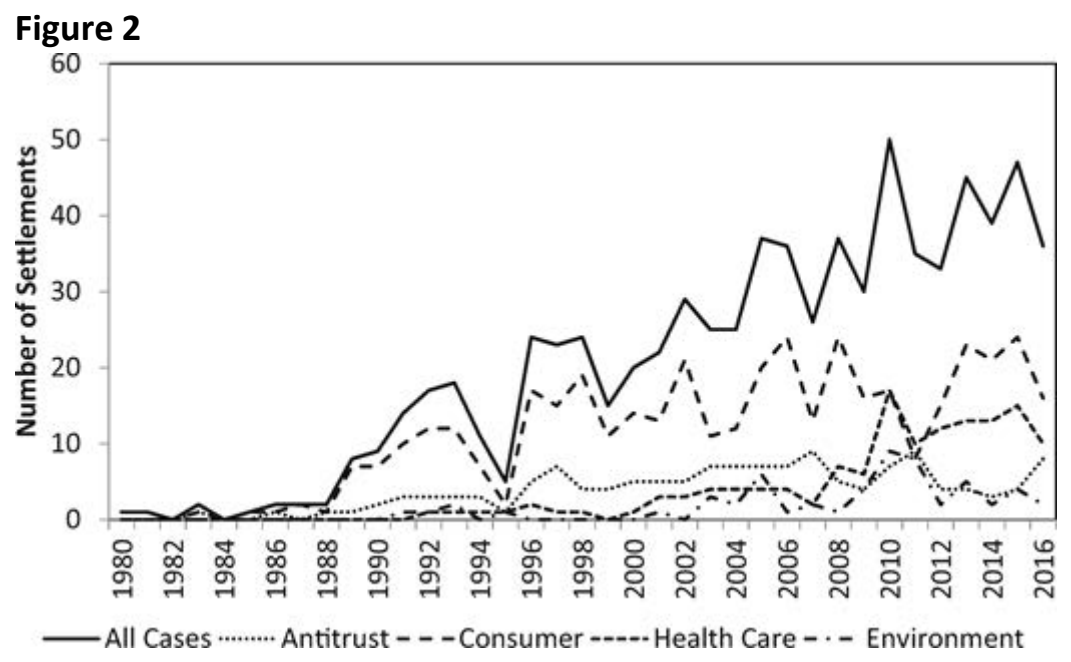

Number of multi-state lawsuits brought against businesses, 1980-2017.

In subsequent administrations, the number of lawsuits increases, as does the scope of policy areas targeted by the AGs. AGs filed a total of 237 lawsuits during the Bush Administration and while consumer protection cases still comprised the majority, it was a smaller proportion at 138 cases (58 percent). The number of antitrust cases increased during this period, and health care and environment cases also began to become more prominent. This trend became more pronounced during the Obama 
Administration, as a total of 313 lawsuits were filed, but the proportion of consumer protection cases continued to decline (138 cases -44 percent), at the same time that there was a marked increase in health care lawsuits. In the Trump Administration, the trend continues in a similar fashion, as thirtythree lawsuits were filed in the first year alone. More importantly, the number of consumer protection and health care lawsuits is similar, reflecting the growing importance of health care-related lawsuitsmost of which involved Medicaid fraud claims against pharmaceutical companies.

The total number of annual lawsuits in different policy areas demonstrates the overall salience of multistate litigation as well as which policy areas within multi-state litigation are gaining or losing salience. However, average participation rates across different types of lawsuits add a measure of salience which can also reveal the willingness of AGs to cooperate with each other. Table 2 reveals the average proportion of Republican and Democrat AG participation in different types of lawsuits across the four presidencies. ${ }^{4}$ We call this proportion the average proportion of participation (APP) for Democrats and Republicans. Cases in which there are higher APPs for both Democrats and Republicans indicate greater potential for bipartisan behavior, while partisan gaps in participation reveal greater enthusiasm for those particular cases by one party.

The table contains the already mentioned categories of consumer protection, health care and environmental cases, but it further divides antitrust cases into merger reviews and those involving all other antitrust infractions (price fixing, monopolization, bid-rigging, and horizontal/vertical restraintslabelled "antitrust" in the table). The APP for both parties in merger review cases is less than 25 percent for all presidents, whereas it is considerably higher for all other antitrust cases. Even though bipartisan cooperation on antitrust cases appears to decline after the Clinton Administration, the APP is still at least 40 percent in every instance, except for Trump Republican AGs, although there are only two cases to report. Such patterns are consistent with previous research on the subject. Provost $(2010,2014)$ finds that merger reviews do not attract as many AGs, possibly because they do not promise money through settlements, whereas price fixing and monopolization cases often net large settlements from the target companies involved. The promise of large settlements in cases where substantial economic harm has been done is a significant motivator for bipartisan cooperation among AGs.

The APP for each party in consumer protection cases is 34 percent and 31 percent for Democrat and Republican AGs, respectively, under Clinton. These numbers do not reflect overwhelming appetite for consumer protection cases, but the narrow 3 percent gap reveals greater willingness to cooperate on such cases. The APPs for each party increased significantly under Bush, then declined slightly under Obama, even though the overall number of cases continued to increase, particularly from Clinton to Bush. The gap between parties widened a bit under Bush and Obama (7 percent), compared to Clinton, but then widened even more significantly under Trump (11 percent), even though the APP for each party also increases under Trump. These numbers therefore indicate that over time, each party shows a greater willingness to participate in consumer protection cases, but simultaneously, this willingness has increased more rapidly on the Democratic side, with the enthusiasm gap being most noticeable during the Trump Administration.

The average participation rates across administrations for health care and environment cases are a study in contrasts with respect to conflict and cooperation. In environmental cases, the high-water mark 
for Democrats came during the Clinton Administration, but similarly low proportions participated for each party during the Bush and Obama Administrations. The participation gap widened again under Trump, although there is only one case in Trump's first year. Health care fraud cases, on the other hand, appear to generate the most significant level of bipartisan cooperation amongst AGs in all case categories. While relatively uncommon during the Clinton Administration, the number of cases rose significantly in the Bush Administration and skyrocketed during the Obama Administration. The APPs for these cases during the Bush and Obama years are the highest in table 2, revealing the rising importance of health care and pharmaceutical cases, as well as the potential for large settlements in such cases (Nolette 2015b). As of this writing, the final tally of participating states in many of the health care settlements so far in the Trump Administration had not yet been finalized; therefore, we do not include the APP for those settlements in table 2. However, most of these settlements-such as a December 2017 settlement with Boehringer Ingelheim Pharmaceuticals over deceptive marketing claims and a September 2017 settlement with Novo Nordisk over the company's failure to communicate risks associated with a diabetes drug-appeared to be attracting large, bipartisan AG coalitions based upon the states joining the settlements so far. That bipartisan activity is consistent with health care-related lawsuits against corporations in previous administrations, as well as with the major AG opioid investigation discussed below.

\section{Table 2}

Average proportions of participation (APPs) of Democrat and Republican AGs across policy areas and presidential administrations in multi-state cases against businesses

$\begin{array}{lllll} & \text { Clinton } & \text { Bush } & \text { Obama } & \text { Trump } \\ \text { Antitrust-Democrat } & 0.56(N=18) & 0.44(N=38) & 0.40(N=26) & 0.45(N=2) \\ \text { Antitrust-Republican } & 0.55(N=18) & 0.42(N=38) & 0.42(N=26) & 0.38(N=2) \\ \text { Merger Review-Democrat } & 0.09(N=14) & 0.18(N=14) & 0.17(N=12) & 0.21(N=3) \\ \text { Merger Review-Republican } & 0.11(N=14) & 0.11(N=14) & 0.12(N=12) & 0.08(N=3) \\ \text { Consumer Protection-Democrat } & 0.34(N=97) & 0.50(N=138) & 0.47(N=140) & 0.58(N=14) \\ \text { Consumer Protection-Republican } & 0.31(N=97) & 0.43(N=138) & 0.40(N=140) & 0.47(N=14) \\ \text { Health Care-Democrat } & 0.28(N=8) & 0.80(N=31) & 0.63(N=96) & \text { N/A (N=13) } \\ \text { Health Care-Republican } & 0.30(N=8) & 0.78(N=31) & 0.63(N=96) & N / A(N=13) \\ \text { Environment-Democrat } & 0.28(N=3) & 0.11(N=16) & 0.11(N=36) & 0.48(N=1) \\ \text { Environment-Republican } & 0.11(N=3) & 0.07(N=16) & 0.10(N=36) & 0(N=1)\end{array}$

-Antitrust Cases Consist of Monopolization, Price Fixing, Bid Rigging, and Horizontal/Vertical Restraint Cases. - Healthcare participation data are incomplete for the Trump Administration, which is reflected by the N/A in this table. We provide qualitative examples of health care lawsuits during the Trump Administration in the text.

\section{Multistate Cooperation: Drug Companies and Opioids}

As indicated in table 2, multi-state cases against business often generate the opportunity for large-scale cooperation because the alleged offense has nationally felt effects and/or because the monetary settlement is too large to turn away. In this section, we focus on the most prominent example of this 
dynamic so far in the Trump Administration: bipartisan AG cooperation to tackle the growing opioid epidemic.

Beginning the late 1990s, the number of opioid overdoses has grown to epidemic levels as the nonmedical use of these drugs has soared. The sharp rise in opioid overdose deaths -540 percent over three years-was the main factor in the increase in overall drug overdose deaths that in 2016 alone claimed roughly 64,000 American lives (Katz 2017). While President Trump declared a public health emergency over opioid abuse in the summer of his first year, both he and Congress faced criticism that they were not taking aggressive enough action to tackle the crisis.

Instead, the most aggressive actions have come from the states alongside other jurisdictions. Through numerous investigations and lawsuits, AGs have employed their substantial legal tools to generate pressure on manufacturers of prescription opioids to change their business practices. Despite the growing partisanship amongst AGs on many other issues, AGs' efforts in this area featured considerable bipartisan and intergovernmental cooperation. Ohio AG Mike DeWine, a Republican, followed Mississippi Democrat Jim Hood's pioneering 2015 lawsuit with one of his own against five major opioid manufacturers in May 2017. Like the earlier Mississippi suit-and with the assistance of the same class action attorneys that had been working with AG Hood-DeWine's lawsuit claimed that the defendant companies engaged in a "marketing scheme" to persuade doctors and patients that powerful opioids were appropriate and safe treatments for chronic pain. "We believe that the evidence will show that these pharmaceutical companies purposely misled doctors about the dangers connected with pain meds that they produced, and that they did so for the purpose of increasing sales," DeWine argued. "And boy, did they increase sales" (Dwyer 2017). The lawsuit sought restitution for the amount the state's Medicaid program paid for "excessive" opioid prescriptions as well state costs associated with drug addiction prevention and treatment. It also seeks injunctive relief ordering the company to cease misrepresenting the risks and benefits of opioids for the treatment of chronic pain (Ohio Attorney General 2017).

DeWine's lawsuit opened the floodgates for subsequent coordinated AG activity in 2017. Only two weeks after DeWine announced his lawsuit, several AGs announced that they were working together in a bipartisan coalition to probe the effects and legality of drug companies' marketing of opioids. Members of the coalition, later revealed to include at least forty-one of the nation's AGs, spanned the political spectrum from liberal Massachusetts AG Maura Healey to conservative Texas AG Ken Paxton. Their goal, the AGs argued, was to force the companies to provide more information about their opioid promotion strategies over the previous two decades. As Healey put it, the probe sought to discover "what did they know and when did they know it? Did they know how addictive these drugs were when they sold them? Did they mislead patients into thinking that these drugs were safe? The American people deserve answers. And we're going to get them" (Stout 2017).

The coalition subsequently took the unusual step of publicly revealing specific details of their ongoing investigation, announcing in September 2017 that the AGs had issued several investigative subpoenas and document requests to the same five opioid manufacturers named in Ohio's ongoing lawsuit. ${ }^{5}$ The coalition also revealed that it had issued subpoenas to three pharmaceutical distribution companiesAmerisourceBergen, Cardinal Health, and McKesson-that collectively managed 90 percent of the country's opioid distribution (New York Attorney General 2017c).

The inclusion of opioid distributors in the AGs' broader investigation was indicative of the continued expansion of AGs' efforts beyond a focus on drug companies. On the day before the coalition's 
subpoena announcement, for example, a bipartisan group of thirty-seven AGs sent a letter to the health insurance industry's main trade association urging that its members examine how their payment and coverage policies might contribute to the opioid epidemic. The letter urged insurance companies to adopt "an incentive structure that rewards the use of non-opioid pain management techniques for chronic, non-cancer pain" (NAAG 2017a). A month later, another bipartisan group of AGs sent a letter to several pharmacy benefit managers, including Express Scripts and Humana, urging that they adopt several new measures aiming to mitigate opioid abuse (Connecticut Attorney General 2017). This included limiting certain opioid prescriptions to no more than seven days, one of several measures that CVS Pharmacy had adopted in September 2017-a corporate announcement coming only days after the AGs announced their expanded investigation against a wide range of companies involved in opioid distribution (Park 2017).

The expansion of AGs' legal strategies has occurred alongside coordinated actions by others across the intergovernmental landscape. In July 2017, the Department of Justice announced that over 400 people had been charged with health care fraud involving prescription painkillers in the single largest enforcement action by the intergovernmental Medicaid Fraud Strike Force (Horwitz and Merle 2017). The following month, U.S. Attorney General Jeff Sessions announced the creation of an Opioid Fraud and Abuse Detection that would work closely with AGs and others to prosecute fraud in the opioid industry (Department of Justice 2017). The Drug Enforcement Agency proposed creating its first-ever dedicated group of prosecutors, which would focus on opioid-related fraud and coordination with state and local partners (Drug Enforcement Administration 2017).

Trump himself announced the formation of the President's Commission on Combating Drug Addiction and the Opioid Crisis early in his administration, eventually declaring the crisis to be a "public health emergency" (White House 2017). The FDA took additional actions, including a successful effort to have Endo Pharmaceuticals remove its extended-release opioid Opana ER from the market (Ramsey 2017). Meanwhile, several localities brought litigation against the opioid industry, including Chicago; Dayton, Ohio; nine New York counties; and the Cherokee Nation tribal government. These complaints mirrored those in the AGs' suits, a coordinated strategy made easier since many of the same plaintiffs' attorneys working with the AGs were also retained by the local governments (Hegyi 2017).

This intergovernmental coordination to address the opioid epidemic has not been without hitches. President Trump's announcement of an opioid public health emergency in October 2017 came attached with no new federal money, prompting Massachusetts AG and frequent Trump critic Maura Healey to declare that "this president has yet to put out a game plan, [and] has yet to put his money where his mouth is" (Boigon 2017). It was also revealed that the president's (since withdrawn) drug czar nominee, former U.S. Representative Tom Marino, had been the lawmaker responsible for legislation hamstringing the DEA's enforcement efforts against opioid manufacturers (Gearan et al. 2017). Nevertheless, the coordinated and bipartisan efforts to combat opioid abuse in the early part of the Trump Administration has largely been a stark contrast to the escalating intergovernmental conflict on numerous other issues.

\section{Goals and Strategies of AG Coordination}

AGs have not been alone in taking actions to address the opioid issue, but their tools as the legal representatives of their states provide them a significant national role. For one, their wide subpoena powers grant them the ability to uncover potentially damaging information about what and when corporate executives knew about the dangers of opioid addiction. Additionally, because they represent 
their state's interest, they can tie any fraudulent corporate behavior to direct harms to their clientspecifically, additional costs to their state's budget. These unique advantages are a key reason why, for example, "lawsuits against Purdue [Pharma] by state officials have been far more successful than individual suits or [private] class actions" (Ausness 2014, 1146). The AGs' now years-long experience in pharmaceutical anti-fraud litigation to tackle other alleged abuses by drug companies provides further advantages by giving them a base of experience to make similar claims against the opioid industry (Nolette 2015b).

As noted earlier, AGs have frequently turned to multistate litigation to spur nationwide industry reform. The opioid litigation promises to be one of the largest such efforts in the history of modern AG activism, especially as the campaign has spread from focus on one industry leader (Purdue Pharma, the manufacturer of OxyContin) to targeting a far wider range of opioid industry targets. The AGs' wideranging legal strategy is reminiscent of their 1998 settlement with the tobacco industry that led to over $\$ 200$ billion in payments to the states and various regulatory restrictions on tobacco marketing and changes to industry practices (Derthick 2002). Indeed, AGs' complaints in the opioid lawsuits have made the connection explicit, accusing the drug companies of "borrowing a page from Big Tobacco's playbook" by engaging in efforts to mask the addictiveness of their products. Like the tobacco litigation, the AGs seek to link the companies' allegedly fraudulent behavior with increased costs to state programs like Medicaid. By including as many industry leaders as possible in the investigation, it increases the potential that any regulatory provisions of a global settlement will reach across the entire opioid industry. Given the similarities, it is little surprise that the private attorneys AGs have retained to assist with the litigation include several veterans of the tobacco litigation, including prominent classaction attorney Steve Berman and former Mississippi AG Mike Moore (Deprez and Barrett 2017). Such retentions, while being reminiscent of the tobacco litigation, are also indicative of the expanding policy networks in which AGs operate, especially since these plaintiff attorneys also worked with local governments on their similar lawsuits.

In addition to their official legal actions, the AGs have contributed to the national conversation through use of their considerable soft power. Simply by announcing a major multistate investigation into potential fraud both helps elevate the national salience of the opioid epidemic and suggests a culprit well before any legal issues are resolved in court. These announcements characterize the subjects of the investigation as blameworthy; Republican New Jersey AG Christopher Porrino's rhetoric after suing Purdue Pharma in October 2017 is typical: "when we point the finger of blame for the deadly epidemic that has killed thousands in New Jersey, Purdue is in the bullseye of the target. Today, my office took the first step toward holding them legally and financially responsible for their deception" (New Jersey Attorney General 2017). Companies have typically responded by claiming they are free from wrongdoing and that they were simply working within the framework the FDA allowed, but AGs have already demonstrated in other contexts that bipartisan accusations can help shape public opinion about the company's role in alleged fraud (Nolette 2015b).

By increasing the salience of the opioid issue and shaping the narrative of corporate responsibility for the crisis, AGs have helped place indirect pressure on other institutions to act. They have often followed this up with direct lobbying efforts, sending letters urging Congress to allocate more funds to assist those with opioid addiction and the FDA to adopt stricter limits on opioid prescriptions (e.g., NAAG 2017b). As noted earlier, they have also urged companies involved in the distribution of prescription opioids to change their practices as well-one that carries an implied threat that investigations or litigation could follow the lack of voluntary action. 
The AGs' opioid efforts illustrate the continuing possibilities for bipartisan multistate cooperation even as partisanship amongst the AGs has grown. This is despite that the opioid issue is not immune from potential ideological splits. After all, health care remains a highly polarized area in national politics, and a key aspect of the AGs' involvement in this area is to achieve greater government expenditures to address the crisis as well as stronger government regulation of private industry.

That this issue has maintained a bipartisan cast even in an increasingly polarized political environment is due to at least a few factors. For one, the sheer growth in overdose-related deaths over a short amount of time-up 540 percent in just three years - has contributed to the characterization of opioid addiction as a "crisis" not easily ignored by politicians across the political spectrum. That the epidemic has been especially concentrated among more rural communities and states, areas that Republican politicians increasingly represent, may also place pressure on Republicans otherwise skeptical of government regulation to act. Unlike with mass shooting casualties-another area witnessing a sharp uptick in recent years-opioid deaths are not explicitly linked to an already polarized set of issues (like gun control). Indeed, politicians of both parties have increasingly moved away from viewing drug addiction as an issue of individual crime and towards discussing it as a matter of public health, thus opening the door to potentially bipartisan solutions (Dagan and Teles 2016).

Additionally, Republican AGs specifically have been on board with aggressive theories of corporate fraud for years when it comes to the pharmaceutical industry, joining and often leading multistate campaigns to change drug company practices through litigation. In that sense, the opioid litigation is another facet of a campaign that has already long forged bipartisan AG cooperation. Finally, this investigation promises to generate large settlements directing money to state coffers. As of this writing, the opioid suits have been consolidated in federal court in Cleveland, where the judge is pressuring both sides to reach a settlement agreement likely to reach well into the billions of dollars (Hoffman 2018). As with other multistate efforts where large settlements are involved, the prospect of otherwise losing out on settlement proceeds tends to push more AGs to join the settlement.

\section{Discussion and Conclusion}

In this article, we build upon existing research on state AGs and American federalism to analyze conflict and cooperation among the states' chief law enforcement officers. Conflict has continued unabated in litigation against the federal government, as well-organized and partisan groups of AGs have in recent years taken aim at federal policies in a wide range of areas. This pattern has accelerated in the Trump Administration, as the polarization and divisions surrounding the 2016 election have now assumed the form of highly partisan policy conflicts. Democratic AGs, in vehement disagreement with the Trump administration's stances on immigration, education, environment, financial regulation, have initiated a frenzy of litigation to stop what they see as a dangerous agenda-in much the same way that Republican AGs took action against the Obama administration. As we show, such conflict has been particularly notable in environmental policy, a significant area of litigation against the federal government. Conflict has, however, spread to many other areas of policy. The partisan behavior that is apparent in litigation is evident in other multistate actions as well, including the filing of amicus briefs in federal court and letter-writing efforts directed to federal policymakers.

At the same time, AGs have found areas of bipartisan cooperation when the target is the private sector. Such lawsuits can attract the participation of most or all states if the alleged offense is widespread or if enough state AGs are interested in the potential gains from joining. Our data show that multi-state lawsuits in health care-where pharmaceutical companies are frequently the target-typically have at 
least thirty states participating. The investigation of pharmaceutical companies in the opioid crisis has been a model of bipartisan cooperation, as the crisis is widespread with the potential to generate large monetary settlements.

Within these broad trends of conflict and cooperation, we have identified several smaller, yet important patterns in AG policymaking. First, the pace at which lawsuits have been filed both against the federal government and against private industry is staggering. This is partly a reflection of how important AGs have become and how their form of policymaking has become firmly entrenched and institutionalized. It is also a product of the high level of polarization the United States has experienced during the Obama and Trump Administrations. The conflict and intense level of activity are also a result of the expanded policy networks in which AGs surround themselves. As the effects of AG activities have reverberated throughout American policymaking venues, organized interests are increasingly likely to organize directly with or parallel to AG activities. Groups such as the NRDC act as loosely aligned allies to Democratic AGs in environmental protection, while energy companies act as both allies and lobbyists to Republican AGs. In the opioid crisis, plaintiff attorneys act as contracted agents of AG offices, where AGs might be lacking the resources to move forward entirely on their own.

Second, with this increased power and status, AGs have continued to find ways to bolster their arsenal of legal and policymaking tools. AGs have used soft power by increasingly engaging in written correspondence, particularly with federal government officials. These letters often serve to inform, but they also serve as the immediate first step toward subsequent legal action. Additionally, state AGs have often displayed the ability to be legally innovative and entrepreneurial, crafting legal theories that succeed in getting cases moved towards successful resolution. In the opioid case study, Ohio AG DeWine postulated that opioid use had a draining effect on the state's Medicaid fund-a legal theory that provided the foundation for his case against big pharma. This idea, which echoes the underlying theory behind the tobacco litigation from twenty years earlier, was instrumental in getting many more AGs to subsequently sign on to the investigation. As the opioid case study illustrates, these developments raise important questions about whether these investigations have the potential to become as significant as the tobacco litigation of the 1990s.

This research on AGs raises several other important questions and potentially fruitful avenues for research. First, what do the close working relationships between state AGs, trial lawyers and lobbyists portend for the work of AGs? Several commentators have argued that these relationships undermine the institutional legitimacy of the office, as they lead AGs to work not for the public interest, but rather specific private interests. Scholars of state AGs would be wise to study the origins of future cases, as well as the alliances that help to bring those cases. Second, measuring AGs' effectiveness in pushing federal policy one way or another is an enormously important task. If AGs achieve meaningful settlements, win lawsuits against the federal government, or influence courts through friend-of-the-court briefs, it is an indicator that their increased clout is having a significant effect. Finally, while state AGs have often taken their fight to the federal government, they have also taken the fight to the cities. AGs have increasingly turned to litigation to stifle local government policies with which they disagree (Riverstone-Newell 2017). As cities exert themselves further in ways that diverge from the partisan interests of their states, federalist battles may become even more multi-layered, with alliances developing and disintegrating according to the moment's balance of power.

This is hardly a comprehensive list of future research avenues related to state AGs and federalism, but it is a promising one. The answers to these and other questions will continue to be important to scholars 
of American federalism as AGs become further entrenched in national policymaking during the Trump era.

\section{Footnotes}

We would like to thank John Dinan, the editor, and the four anonymous reviewers for their helpful comments on this article.

1 Data on multi-state lawsuits come from searches through Lexis-Nexis "United States News Verdicts, Settlements and Decisions" database. These data were supplemented with data from publications of the National Association of Attorneys General (NAAG), including the AG Bulletin, the Consumer Protection Report, Antitrust Report, Telemarketing Fraud Bulletin, Medicaid Fraud Report, and the NAAG National Environmental Enforcement Journal. Data on amicus briefs come primarily from a search through the Lexis Nexis database "U.S. Supreme Court Briefs". Data on multistate letters and comments were identified via a search of press releases issued by each of the AGs' offices.

2 While we define "partisan brief" as one in which 80 percent of the signatories are from one party, the patterns described here are the same if one instead applies a 70, 90, or 100 percent cutoff. Regardless of which of these percentages is used, 2017 featured the highest percentage of partisan briefs of any year in the dataset.

3 We use the same criteria to define a "partisan" letter or comment as we do for "partisan" amicus brief filings earlier, namely when 80 percent or more of the AG signatories are from one party. As with amicus briefs, the trends discussed here do not differ if one uses a 70, 90, or 100 percent alternative cutoff to define "partisan."

4 For each case, we divided the number of Republican and Democrat AGs participating in the lawsuit by the total number of Republican and Democrat AGs, respectively. We then averaged these participation rates across policy areas and presidencies, as Table 2 reflects.

5 The five companies were Endo, Janssen, Teva, Allergen, and Purdue Pharma.

\section{References}

Ausness Richard. 2014. The role of litigation in the fight against prescription drug abuse. West Virginia Law Review 116 3: 1117-1165.

Biskupic Joan. 2012. Analysis: State attorneys general: new Republican power. Reuters, April 24.

Boigon Molly. 2017. AG Healey: Trump needs to "put his money where his mouth is" on opioids. WGBH, October 26.

Bowman Ann O'M. 2004. Horizontal federalism: Exploring interstate interactions. Journal of Public Administration Research and Theory 14 1: 535-546.

Bowman Ann O'M., Krause George. 2003. Power shift: Measuring policy centralization in U.S. intergovernmental relations, 1947-1998. American Politics Research 31 3: 301-325.

Bulman-Pozen Jessica. 2014. Partisan federalism. Harvard Law Review 127 4: 1077-1146.

Broder John M. 2008. Obama affirms climate change goals. New York Times, November 18.

California Attorney General. 2017. Final comments on the EPA methane Rule, August 9 , https://ag.ny.gov/sites/default/files/state final comment letter re epa methane rule stay 0 $\underline{02 . p d f}$

Calvani Terry. 1989. Advertising regulation: States v. FTC. Antitrust Law Journal 58: 253-266.

Clayton Cornell W. 1994. Law, politics and the new federalism. State and Local Government Review 49 3: 281-307. 
Conlan Timothy. 1991. And the beat goes on: Intergovernmental mandates and preemption in an era of deregulation. Publius: The Journal of Federalism 21 3: 43-57.

Conlan Timothy. 2017. The changing politics of American federalism. State and Local Government Review 49 3: 170-183.

Conlan Timothy, Posner Paul. 2016. American federalism in an era of partisan polarization: The intergovernmental paradox of Obama's 'new nationalism'. Publius: The Journal of Federalism 46 3: 281-307.

Connecticut Attorney General. 2017. Letter to express scripts, et al., October 19. http://www.ct.gov/ag/lib/ag/press releases/2017/20171020 letters cvs pmbs opioidmitigatio $\underline{\text { n.pdf. }}$.

Dagan David, Teles Steven. 2016. Prison Break. New York: Oxford University Press.

Davenport Coral. 2015. Obama's strategy on climate change, part of global deal, is revealed. New York Times, March 31.

Davenport Coral. 2017. Scott Pruitt is seen cutting the EPA with a scalpel, not a cleaver. New York Times, February 5.

Davenport Coral, Lipton Eric. 2017. How GOP leaders came to view climate change as fake science. New York Times, June 3.

Davenport Coral, Davis Julie Hirschfeld. 2015. Move to fight Obama's climate plan started early. New York Times, August 3.

Davenport Coral, Rubin Alissa. 2017. Trump signs executive order unwinding Obama climate policies. New York Times, March 28.

Debenedetti Gabriel. 2017. Trump opposition sets up blue-state headquarters. Politico, January 8.

Department of Justice. 2017. Attorney General sessions announces opioid fraud and abuse detection unit, August 2. https://www.justice.gov/opa/pr/attorney-general-sessions-announces-opioidfraud-and-abuse-detection-unit.

Deprez Esme, Barrett Paul. 2017. The lawyer who beat big tobacco takes on the opioid industry. Bloomberg, October 5.

Derthick Martha.2002. Up in smoke: From legislation to litigation in tobacco politics. Washington D.C.: Congressional Quarterly Press.

Drug Enforcement Administration. 2017. Program to hire special assistant United States attorneys in targeted federal judicial districts utilizing diversion control fee account funds, March 21. https://www.federalregister.gov/documents/2017/03/21/2017-05396/program-to-hire-specialassistant-united-states-attorneys-in-targeted-federal-judicial-districts.

Dwyer Colin. 2017. Ohio sues 5 major drug companies for "fueling opioid epidemic". National Public Radio, May 31.

Flitter Emily. 2017. Court rejects Trump administration move to delay methane regulation. Reuters, July 3.

Gearan Anne, Bernstein Lenny, Higham Scott, O’Keefe Ed. 2017. Trump says drug czar nominee Tom Marino is withdrawing after Washington Post/'60 minutes' investigation. Washington Post, October 17.

Heikkinen Niina. 2018. State attorneys to Pruitt: Repeal, don't replace. Climatewire, March 6.

Hegyi Nate. 2017. Cherokee nation sues Wal-Mart, CVS, Walgreens over tribal opioid crisis. National Public Radio, April 25.

Hoffman Jan. 2018. Can this judge solve the opioid crisis?. New York Times, March 5.

Horwitz Sari, Merle Renae. 2017. DOJ announces charges against 400 people for $\$ 1.3$ billion in healthcare fraud. Washington Post, July 13.

Howell Tom Jr. 2013. Republican attorneys general see Obama misuse of power. Washington Times, February 26. 
Hurley Lawrence. 2016. Democratic states vow to fight Trump in court. Reuters, November 18.

Jensen Jennifer M. 2017. Governors and partisan polarization in the federal arena. Publius: The Journal of Federalism 47 3: 314-341.

Katz Josh.2017. The first count of fentanyl deaths in 2016: Up 540\% in three years. New York Times, September 2.

Kincaid John. 1990. From cooperative to coercive federalism. The Annals of the Academy of Political and Social Science 509 1:139-152.

Lipton Eric. 2014. Lobbyists, bearing gifts, pursue attorneys general. New York Times, October 28.

Lynch Jason. 2001. Federalism, separation of powers and the role of state attorneys general in multistate litigation. Columbia Law Review 101 8:1198-2032.

McQuaid John. 2017. Make America wait again: Trump tries to delay regulations out of existence. Scientific American, July 24.

Neuhauser Alan. 2017. State attorneys general lead the charge against Donald Trump. US. News and World Report, October 27.

NAAG. 2017a. Letter to America's Health Insurance Plans, September 18. https://ag.ny.gov/sites/default/files/final naag opioid letter to ahip.pdf.

NAAG. 2017b. Letter to Speaker of the House, October 2. http://www.naag.org/assets/redesign/files/sign-onletter/Final\%20Draft1\%20-\%20Road\%20to\%20Recovery.pdf.

New Jersey Attorney General. 2017. Attorney General Porrino announces suit against Purdue Pharma, October 31. http://nj.gov/oag/newsreleases17/pr20171031a.html.

New York Attorney General. 2017a. A.G. Schneiderman scores victory for New Yorkers against Trump's EPA, August 3.

New York Attorney General. 2017b. AG Schneiderman, fellow AGs urge Trump administration to reconfirm U.S. commitment to the Paris Climate Agreement, April 25. https://ag.ny.gov/pressrelease/ag-schneiderman-fellow-ags-urge-trump-administration-reconfirm-us-commitmentparis.

New York Attorney General. 2017c. A.G. Schneiderman, bipartisan coalition of AGs expand multistate investigation into opioid crisis, September 19. https://ag.ny.gov/press-release/agschneiderman-bipartisan-coalition-ags-expand-multistate-investigation-opioid-crisis.

Nolette Paul. 2014. State litigation during the Obama administration: Diverging agendas in an era of polarized politics. Publius: The Journal of Federalism 44 3: 451-474.

Nolette Paul. 2015a. Federalism on trial: State attorneys general and national policymaking in contemporary America. Lawrence: University Press of Kansas.

Nolette Paul. 2015b. Law enforcement as legal mobilization: Reforming the pharmaceutical industry through government litigation. Law \& Social Inquiry 40 1: 123-151.

Nolette Paul. 2017. The dual role of state attorneys general in American federalism: Conflict and cooperation in an era of partisan polarization. Publius: The Journal of Federalism 47 3: 342-377.

Ohio Attorney General. 2017. Attorney general DeWine files lawsuit against opioid manufacturers for fraudulent marketing; fueling opioid epidemic, May 31. http://www.ohioattorneygeneral.gov/Media/News-Releases/May-2017/Attorney-GeneralDeWine-Files-Lawsuit-Against-Opio.

Olson Adam, Callaghan Timothy, Karch Andrew. 2018. Return of the "rightful remedy": Partisan federalism, resource availability, and nullification legislation in the American States. Publius: The Journal of Federalism 48 3: 495-522.

Park Alice. 2017. CVS pharmacy will limit prescriptions for opioids. TIME, September 22. 
Pew Research Center. 2017. The partisan divide on political values grows even wider, October 5. http://www.people-press.org/2017/10/05/the-partisan-divide-on-political-values-grows-evenwider/.

Provost Colin. 2003. State attorneys general, entrepreneurship, and consumer protection in the new federalism. Publius: The Journal of Federalism 33 2: 37-53.

Provost Colin. 2010. An integrated model of state attorney general behavior in multi-state litigation. State Politics and Policy Quarterly 10 1: 1-24.

Provost Colin. 2014. Antitrust law and distributive politics in the American states. Law and Policy 36 4: 408-431.

Ramsey Lydia. 2017. A painkiller at the heart of the opioid epidemic has been taken off the market. Business Insider, July 6.

Rhode Island Attorney General. 2017. Press release: Attorney General Peter Kilmartin leads coalition urging congress to reject proposals to gut EPA. March 30. http://www.ri.gov/press/view/30000.

Riverstone-Newell Lori. 2017. The rise of state preemption laws in response to local policy innovation. Publius: The Journal of Federalism 47 3: 403-425.

Siciliano Jonathan. 2017. State Attorneys General lend Trump legal advice on leaving climate deal. Washington Examiner, May 24.

Stempel Jonathan. 2017. Environmental group sues EPA for revoking mercury protection rule. Scientific American, February 1.

Stout Matt. 2017. AG targets marketing, production of opiates. Boston Herald, September 19.

Valdmanis Richard. 2017. States challenge Trump over clean power plan. Scientific American, April 6. Volcovici Valerie. 2018. Federal court orders EPA to implement smog rules. Reuters, March 12.

White House. 2017. President Donald J. Trump is taking action on drug addiction and the opioid crisis, October 26. https://www.whitehouse.gov/the-press-office/2017/10/26/president-donald-jtrump-taking-action-drug-addiction-and-opioid-crisis.

Zimmerman Joseph. 1998. Interstate cooperation: The roles of state attorneys general. Publius: The Journal of Federalism 28 1: 71-89. 